\title{
触 New Disease Reports \\ First report of Phytophthora taxon niederhauserii causing decline of almond in Turkey
}

I. Kurbetli* and K. Değirmenci

Plant Protection Central Research Institute, 06172 Ankara, Turkey

*E-mail: kurbetli@gmail.com

Received: 23 Dec 2010. Published: 22 Mar 2011. Keywords: Prunus dulcis, plant disease

Turkey is among the top ten countries for almond (Prunus dulcis) production in the world. In 2009, losses of approximately 5\% were observed in Kayseri province associated with a decline of two-year-old almond trees in an orchard containing 600 almond trees, cvs. Nonpareil, Ferraduel and Ferragnes, originally grown in a nursery in Yalova province. Affected trees developed small chlorotic leaves that wilted, and had cankers on the basal stems. Some of the affected trees had dried completely. Infected stem tissues, cut into nine to ten small pieces $(5 \times 3$ $\mathrm{mm}$ ), were plated onto P5ARPH-CMA (Jeffers \& Martin, 1986) without surface disinfection. Plates were incubated for three to five days at $22^{\circ} \mathrm{C}$ in darkness from which a Phytophthora sp. was consistently recovered. Actively growing mycelium was transferred to carrot piece agar $(40 \mathrm{~g} / \mathrm{l}$ carrot pieces; $20 \mathrm{~g} / \mathrm{l}$ agar) containing $20 \mathrm{mg} / 1 \beta$-sitosterol. The unidentified Phytophthora sp. did not produce sexual structures in single culture. Nonpapillate sporangia, ellipsoid to ovoid with tapered bases, $64.5-83.3 \mu \mathrm{m}$ long (mean $69.3 \mu \mathrm{m}$ ) and 36.1-45.0 $\mu \mathrm{m}$ wide (mean $38.3 \mu \mathrm{m}$ ), with lengthto-width ratios of about 1.8 were produced abundantly in non-sterile soil extract solution. The sporangia proliferated internally or externally, presenting both nested and extended proliferation of the sporangium (Fig. 1). Colonies grew very slowly at $35^{\circ} \mathrm{C}$. Isolates were identified as $P$. taxon niederhauserii by sequence analysis of the ribosomal DNA internal transcribed spacers 1 and 2 using ITS1 and ITS2 primers (GenBank Accession No. HQ681251). The sequence was $99 \%$ identical to sequences of $P$. taxon niederhauserii isolates (AY550915 and FN252859).

One representative isolate was used to inoculate eight two-year-old almond

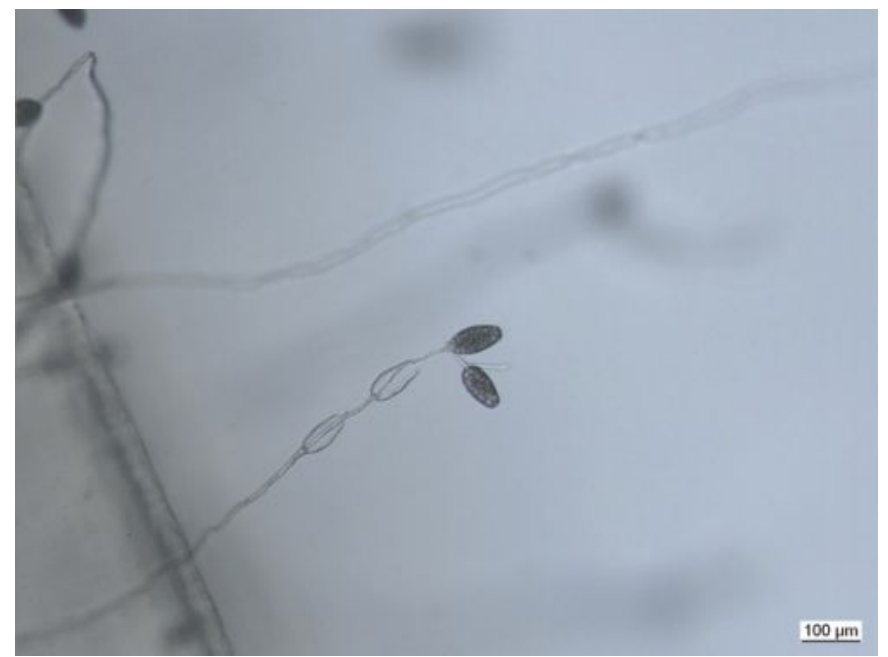

Figure 1 plants with an agar plug of actively growing mycelium that was attached to exposed cambium of the basal stem. Agar plugs without mycelium were used for eight control plants. The plants were kept in a controlled greenhouse at $25^{\circ} \mathrm{C}$ and watered weekly. All plants inoculated with $P$. taxon niederhauserii collapsed after four weeks. Control plants remained healthy (Fig. 2). The pathogen was re-isolated from necrotic basal stems. Phytophthora taxon niederhauserii, proposed as a new species in 2003, was originally isolated from Thuja occidentalis and Hedera helix plants grown in glasshouses in North Carolina, USA. In 2007, it was found on Ceanothus sp. in Santa Barbara County (California, USA). In Australia, it has been detected on imported nursery plants and in natural ecosystems on Banksia prionotes. In Europe, $P$. taxon niederhauserii was detected on potted Callistemon citrinus, Cistus spp., Banksia speciosa, various Begonia hybrids, Hedera helix, Kalanchoe blossfeldiana, Sinningia speciosa, and Peperomia clusiifolia. In Spain, $P$. taxon niederhauserii has been detected on almond trees in 2007 (EPPO, 2009). As far as is known, this is the first report of Phytophthora taxon niederhauserii in Turkey.

\section{References}

EPPO, 2009. New Phytophthora species: Phytophthora niederhauserii.EPPO Reporting Service 2009/197.

Jeffers SN, Martin SB, 1986. Comparison of two media selective for Phytophthora and Pythium species. Plant Disease 70, 1038-1043. http://dx.doi.org/10.1094/PD-70-1038

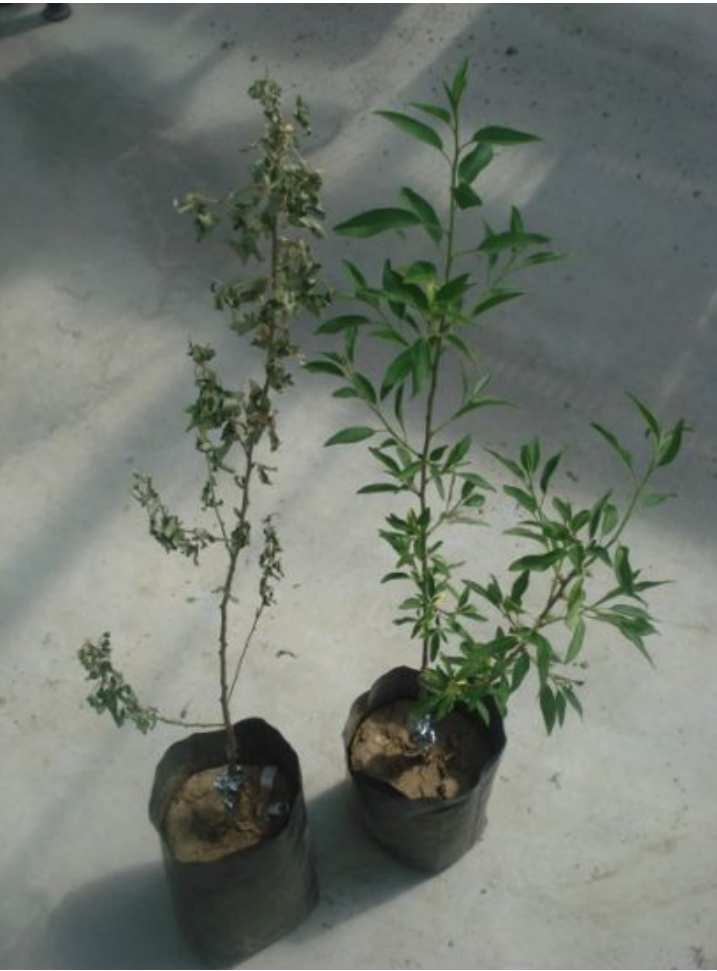

Figure 2

To cite this report: Kurbetli I, Değirmenci K, 2011. First report of Phytophthora taxon niederhauserii causing decline of almond in Turkey. New Disease Reports 23, 14. http://dx.doi.org/10.5197/j.2044-0588.2011.023.014

(C)2011 The Authors

This report was published on-line at www.ndrs.org.uk where high quality versions of the figures can be found. 